\title{
Other official documents
}

\section{EUROPEAN UNION}

Conference of the Representatives of the Member States, Brussels, 23 July 2007, Draft Treaty amending the Treaty of the European Union and the Treaty establishing the European Community, CIG 1/07 228

\section{Council of Ministers}

Joint Statement of the Council and the Commission made at the time when Regulation No 1/2003 was adopted, Brussels 3.3.2003 (13.03) $\mathbf{1 9 0}$

\section{European Parliament}

Report on the proposal for a Council regulation on the control of concentrations between undertakings, Committee on Economic and Monetary Affairs (the "della Vedova Report"), A5-0257/2003 FINAL, 9 July 2003

\section{COMMISSION OF THE EUROPEAN COMMUNITIES}

\section{Decisions}

Terms of Reference of the Hearing
Officer, annexed to the XI Report on Competition Policy, Brussels: 198248

Decision 94/810/ECSC, EC, on the terms of reference of hearing officers in certain competition proceedings, [1994] OJ L330/67 48

Decision 1999//352/EC, ECSC, Euratom of 28 April 1999, [1999] OJ L136/20; Regulation 1073/1999 of 25 May 1999 of the Council and the European Parliament, concerning investigations conducted by the European Anti-Fraud Office (OLAF), [1999] L136/1 241

Decision 2001/462/EC, ECSC, on the terms of reference of hearing officers in certain competition proceedings, [2001] OJ L162/21 49

\section{Notices and guidelines}

Notice on cooperation between national courts and the Commission in applying Articles 85 and 86 of the EEC Treaty, [1993] OJ C39/6 39

Notice on the non-imposition or reduction of fines in cartel cases, [1996] OJ C207/04 28

Notice on the internal rules of procedure for processing requests for 
access to the file in cases pursuant to Article 85 and 86 of the EC Treaty, Articles 65 and 66 of the ECSC Treaty and Council Regulation (EEC) 4064/89, [1997] OJ C23/3 66

Guidelines on the method of setting fines imposed pursuant to Article 15(2) of Regulation No 17 and Article 65(5) of the ECSC Treaty, [1998] OJ C9/3 163

Notice on immunity from fines and reduction of fines in cartel cases, [2002] OJ C45/3 28

Guidelines of best practices on the conduct of EC merger control proceedings, available at: http://europa.eu.int/comm/ competition/mergers/legislation/ regulation/best_practices.pdf $\mathbf{4 2}$ Notice on cooperation within the Network of competition authorities, [2004] OJ C101/43

\section{0}

Notice on cooperation between the Commission and the courts of the EU member states in the application of Articles 81 and 82 EC, [2004] OJ C101/54 195

Notice on the rules for access to the Commission file in cases pursuant to Articles 81 and 82 of the EC Treaty, Articles 53, 54 and 57 of the EEA Agreement and Council Regulation (EC) No 139/2004, [2005] OJ C325/7

\section{4}

Guidelines on the method of setting fines imposed pursuant to Article 23(2)(a) of Regulation No 1/2003, [2006] OJ C210/2 28
Notice on immunity from fines and reduction of fines in cartel cases, [2006] OJ C298/17 196

\section{Reports}

XI Report on Competition Policy, 1982: Brussels 35 XII Report on Competition Policy, 1983: Brussels 37 XIII Report on Competition Policy, 1984: Brussels 48

XXIII Report on Competition Policy,1994: Brussels 48

\section{Other Documents}

Dealing with the Commission: Competition Enforcement, 1997: Brussels: Official Publication Centre 36

White Paper on Modernisation of the rules implementing Articles 85 and 86 [now 81 and 82] of the EC Treaty, [1999] OJ C132/1 38

Green Paper on the review of Council Regulation (EEC) No 4064/89, [2001] OJ C745/6

\section{4}

Submissions received on the Green Paper on the review of Council Regulation (EEC) no 4064/89, available at: http://ec.europa.eu/ comm/competition/mergers/revie w/comments.html 44

Green Paper on conflicts of jurisdiction and the principle of $n e$ bis in idem in criminal proceedings, 23 December 2005, SEC(2005) 1767, $\operatorname{COM(2005)~final~} 696$ 211 
European Competition Network, 'Model leniency programme', Memorandum of 29 September 2006 no 06/356, available at: http://ec.europa.eu/comm/competition/ecn/model_leniency_en.pdf 197

\section{UNITED KINGDOM}

\section{House of Lords Select Committee on the European Union}

XIX Report: Strengthening the role of the Hearing Officer, session 1999/2000 44

XXXII Report: the review of the EC

Merger Regulation, session 2001/2002 43

VI Report: the future status of the EU Charter of Fundamental Rights, session 2002/03 228 $X V$ Report: an EU Competition Court, session 2006-07, 23 April 2007. Available at: http://www. publications.parliament.uk/pa/ld2 00607/ldselect/ldeucom/75/75.pdf 187

\section{Office of Fair Trading}

Powers of Investigation, draft competition law guidelines for consultation, April 2004, OFT 404a 202

\section{IRELAND}

\section{Irish Competition Authority}

Cartel Immunity Programme, 20 December 2001, available at: http://www.tca.ie/EnforcingComp etitionLaw/CartelImmunityProgra mme/CartelImmunityProgramme. aspx $\quad 197$

\section{ITALY}

AUTORITA' GARANTE della CONCORRENZA e del MERCATO, Notice on the nonimposition and reduction of fines under section 15 of Law No 287 of 10 October 1990, available at: http://www.gcm.it/eng/index.htm 197 
Arianna Andreangeli - 9781848442672

Downloaded from PubFactory at 04/26/2023 08:12:34AM 